\title{
Evaluating herbivore management outcomes and associated vegetation impacts
}

\author{
Authors: \\ Rina C.C. Grant ${ }^{1}$ \\ Mike J.S. Peel $^{2}$ \\ Hugo Bezuidenhout ${ }^{3}$ \\ Affiliations: \\ ${ }^{1}$ Scientific Services [Kruger \\ National Park], South African \\ National Parks, South Africa \\ ${ }^{2}$ Animal Production Institute, \\ Agricultural Research \\ Council, South Africa \\ ${ }^{3}$ Conservation Services, \\ South African National Parks, \\ South Africa \\ Correspondence to: \\ Rina Grant \\ Email: \\ Rina.grant@sanparks.org \\ Postal address: \\ Private bag X402, Skukuza \\ 1350 , South Africa \\ Dates: \\ Received: 04 June 2010 \\ Accepted: 10 Mar. 2011 \\ Published: 13 May 2011 \\ How to cite this article: \\ Grant, R.C.C., Peel, M.J.S. \\ \& Bezuidenhout, H., 2011, \\ 'Evaluating herbivore \\ management outcomes \\ and associated vegetation \\ impacts', Koedoe 53(2), \\ Art. \#1008, 15 pages. \\ doi:10.4102/koedoe. \\ v53i2. 1008
}

African savannas are characterised by temporal and spatial fluxes that are linked to fluxes in herbivore populations and vegetation structure and composition. We need to be concerned about these fluxes only when management actions cause the system to shift towards a less desired state. Large herbivores are a key attribute of African savannas and are important for tourism and biodiversity. Large protected areas such as the Kruger National Park (KNP) manage for high biodiversity as the desired state, whilst private protected areas, such as those adjacent to the KNP, generally manage for high income. Biodiversity, sustainability and economic indicators are thus required to flag thresholds of potential concern (TPCs) that may result in a particular set of objectives not being achieved. In large conservation areas such as the $\mathrm{KNP}$, vegetation changes that result from herbivore impact, or lack thereof, affect biodiversity and TPCs are used to indicate unacceptable change leading to a possible loss of biodiversity; in private protected areas the loss of large herbivores is seen as an important indicator of economic loss. Therefore, the first-level indicators aim to evaluate the forage available to sustain grazers without deleteriously affecting the vegetation composition, structure and basal cover. Various approaches to monitoring for these indicators were considered and the importance of the selection of sites that are representative of the intensity of herbivore use is emphasised. The most crucial step in the adaptive management process is the feedback of information to inform management decisions and enable learning. Feedback loops tend to be more efficient where the organisation's vision is focused on, for example, economic gain, than in larger protected areas, such as the KNP, where the vision to conserve biodiversity is broader and more complex.

Conservation implications: In rangeland, optimising herbivore numbers to achieve the management objectives without causing unacceptable or irreversible change in the vegetation is challenging. This manuscript explores different avenues to evaluate herbivore impact and the outcomes of management approaches that may affect vegetation.

\section{Introduction}

Large mammals are a key attribute of African savannas and many national parks and private protected areas have been developed with the aim of protecting and benefitting from these large mammals. These aims are reflected in the mission statement of the South African National Parks (SANParks), namely 'to develop and manage a system of national parks that is representative of the biodiversity, landscapes, and associated heritage assets of South Africa, for the sustainable use and benefit of all' (South African National Parks 2008:4). The herbivore management policy of SANParks states that herbivores are managed primarily as ecosystem drivers and is directed by how much change (through herbivore impacts) is acceptable within the desired state (SANParks 2006). It thus focuses on the importance of spatial heterogeneity and temporal fluxes, and the role of landscape patchiness and disturbance in promoting ecosystem resilience and biodiversity (see Grant et al. 2011; Walker \& Goodman 1983). Large private protected areas adjacent to the Kruger National Park (KNP) have embraced this philosophy since the removal of the fence between them, but the fact that most function at different spatial scales (Peel, Biggs \& Zacharias 1999) influences their specific objectives. Private protected areas also have a more explicit objective of being economically sustainable; for example, the primary objective statement of the Associated Private Nature Reserves is 'to provide for ecologically and aesthetically sustainable (nonconsumptive and consumptive) use of the area for its owners, based on wildlife-focused recreation, tourism and hunting'. (Peel, Stalmans \& Anderson 2009). Scale also influences the management of smaller national parks, which have similar biodiversity objectives to the larger parks, but because animal movement is restricted and areas tend to be less heterogeneous these areas present a unique set of management challenges.

We aim to record the lessons learnt during the adaptive management process, including the development of thresholds of concern, for change in vegetation and herbivore numbers in 
SANParks and private protected areas. The application of these thresholds is discussed using data collected in the KNP, the Associated Private Nature Reserves, Sabi Sand Wildtuin, some smaller national parks and privately owned protected areas.

\section{Outcomes of plant-herbivore interaction for biodiversity}

Biodiversity as referred to in this section is as defined by Noss (1990). Herbivores act not only as important drivers of the savanna ecosystem but also as responders to changes in the ecosystem. The main concerns of plant-herbivore interactions therefore relate to loss of vegetation heterogeneity (and herbivore composition and numbers) as described by Grant et al. (2011). These concerns are related to the outcomes of the ecological processes and their effect on biodiversity as a reflection of the predefined desired state (Biggs \& Rogers 2003). This management philosophy allows significantly more flux in the system than the more precautionary historical approach where the best available information was used to determine the number of animals that could be supported by the available forage (Coe, Cumming \& Phillipson 1976; Fritz \& Duncan 1994; Mentis \& Duke 1976). The precautionary approach focused on animal numbers rather than impact. This approach may, however, still be more useful in smaller, more homogenous private protected areas and conservation areas until our understanding of how to measure herbivore impact and its outcomes has improved. However, managers of conservation areas and the advising scientists in smaller conservation areas have to take into account that the ecosystem outcomes cannot be predicted by the impact of animal numbers alone (Peel, Kruger \& Zacharias 2005). The main factors that interact to deliver various potential outcomes are driven by the values of the community towards a specific desired outcome or state such as a representative herbivore population. The values may include economic goals, goodwill of adjacent stakeholders and/or biodiversity (structure, function and composition at the various scales as defined by Noss [1990]). These values interact with the abiotic template to render a specific community of plants and animals over different temporal and spatial scales (Figure 1).

Most national parks define their desired state with regard to biodiversity as represented by the plant and animal species and the ecosystem processes that used to occur in the region, but this objective is influenced by the economic expectations of the stakeholders. The diversity that can be supported by a protected area is determined by the geomorphological template and climate, which determines the large-scale processes and patterns over time. At the landscape scale and over the medium term, rainfall and soil properties (texture, soil depth, nutrient concentration and moisture) are the most important drivers in African savannas (Peel et al. 2005; Venter, Scholes \& Eckhardt 2003). This forms the template that determines the moisture and nutrients available to plants, which, in turn, influence the habitats utilised by herbivore populations. Herbivores respond indirectly to these drivers and in African savannas $87 \%$ of the variance

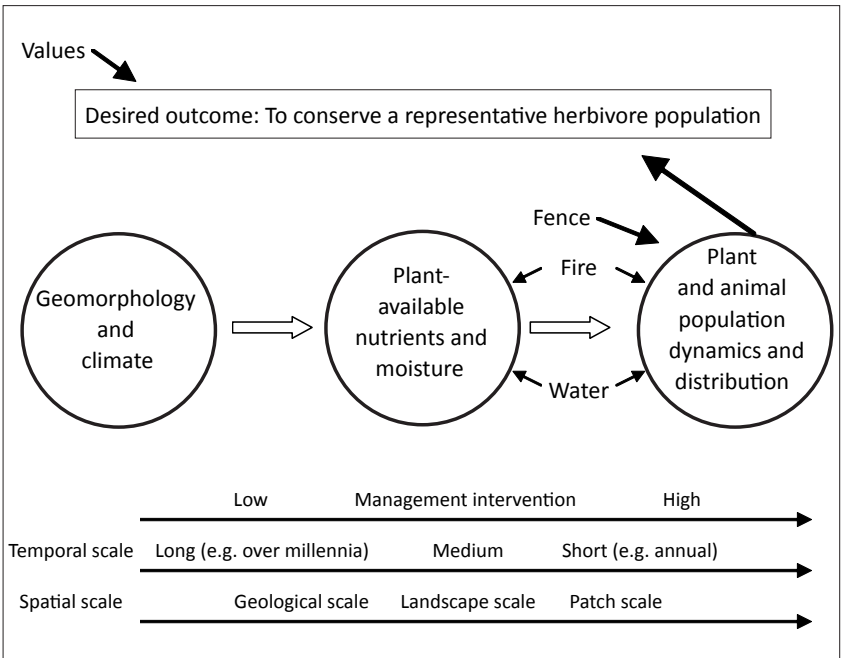

FIGURE 1: A framework illustrating the top-down influences of the herbivore objective as an outcome of the desired state. The herbivore population is influenced by bottom-up processes that effect these populations at different spatial and temporal scales. This determines the options that management has to affect the shorter-term herbivore population outcomes (adapted from Peel, M.J.S., 2005, 'Towards a predictive understanding of savanna vegetation dynamics in the eastern Lowveld of South Africa: with implications for effective management', PhD thesis, University of KwaZulu-Natal).

in large ungulate biomass is explained by soil properties (Fritz \& Duncan 1994). Management of herbivores focuses on shorter-term outcomes and tend to be at smaller spatial scales. Various management factors, such as fences, water distribution and fire, determine these spatial scales. Most stakeholders require protected areas to be fenced to limit transgression by damage-causing animals and to retain ownership of 'their' animals. These fences determine the scale of the area to be managed as well as the type and size of herbivores that can be supported by the area (Du Toit \& Owen-Smith 1989; Peel et al. 1999; Peel et al. 2005). In areas constrained by fences, animals usually have to be supplied with additional water, which not only ensures animal health but also provides tourists with a better wildlife experience by concentrating animals in an area.

Fire is also an important driver of vegetation because fire intensity and frequency affect vegetation structure (Van Wilgen, Govender \& Biggs 2007; Van Wilgen, Govender \& MacFadyan 2008). Furthermore, the interaction between fire and herbivory has a significant effect on woody structure (Figure 2), with fire, elephant and bark-feeding vertebrates all contributing significantly to the mortality of large trees (Bond \& Van Wilgen 1996).

Artificial water is mostly provided to enable animals to forage at a similar intensity over the entire landscape. Depending on the density of animals present, such wide water distribution may lead to homogenisation of vegetation composition and structure (Gaylard, Owen-Smith \& Redfern 2003; Owen-Smith 1996; Walker et al. 1987). The provision of artificial water also influences herbivore composition in that it favours species that are attracted to these water sources, such as zebra (Equus burchelli) and blue wildebeest (Connochaetes taurinus). Other species tend to prefer rivers and drainage lines, such as elephant (Loxodonta africana) 
and impala (Aepyceros melampus), whilst the distribution of browsers is not significantly influenced by the presence of water (Smit, Grant \& Devereux 2007). In smaller, fenced areas in particular, where activities such as tourism, game sales and hunting are an important source of income, water distribution policies generally result in increased water distribution, higher densities of water-dependent herbivores and often, in extreme cases, overutilisation of resources over a wide area (see Figure 2).

Selective herbivory is also a major driver of vegetation structure and composition, creating diversity and heterogeneity at different scales by their preference for certain forage types and patches (Adler, Raff \& Lauenroth 2001; Gordon, Hester \& Festa-Bianchet 2004). Different types of herbivore can be grouped together: bulk grazers such as elephant can change the vegetation significantly from a closed savanna with tall trees to a more open savanna with smaller coppicing trees, whilst white rhino (Ceratotherium simum) can change areas dominated by tuft grasses to ones dominated by lawn grasses (Figure 2). These changes are detrimental to the selective grazers such as sable (Hippotragus niger), which prefer stands of lightly used tall grasslands for hiding their young and as preferred forage (Collinson \& Goodman 1982). Foraging by bulk grazers also favour herbivores that prefer high-quality grazing, such as blue wildebeest, which prefer open patches of short grass. The browsing herbivores, such as kudu (Tragelaphus strepsiceros), that preferentially utilise woody vegetation may be affected by the other herbivores if the available browse is decreased. Small-scale heterogeneity is created and enhanced by selective grazing on patches with short, actively growing grasses such as lawn grasses (Fuhlendorf \& Engle 2001; McNaughton 1979; Stock, Bond \& Van de Vijver 2009), areas of high forage quality such as sodic patches and termite mounds (Grant \& Scholes 2006), or areas with high biomass or quantity of forage (Turner et al. 1997), as illustrated in Figure 2.

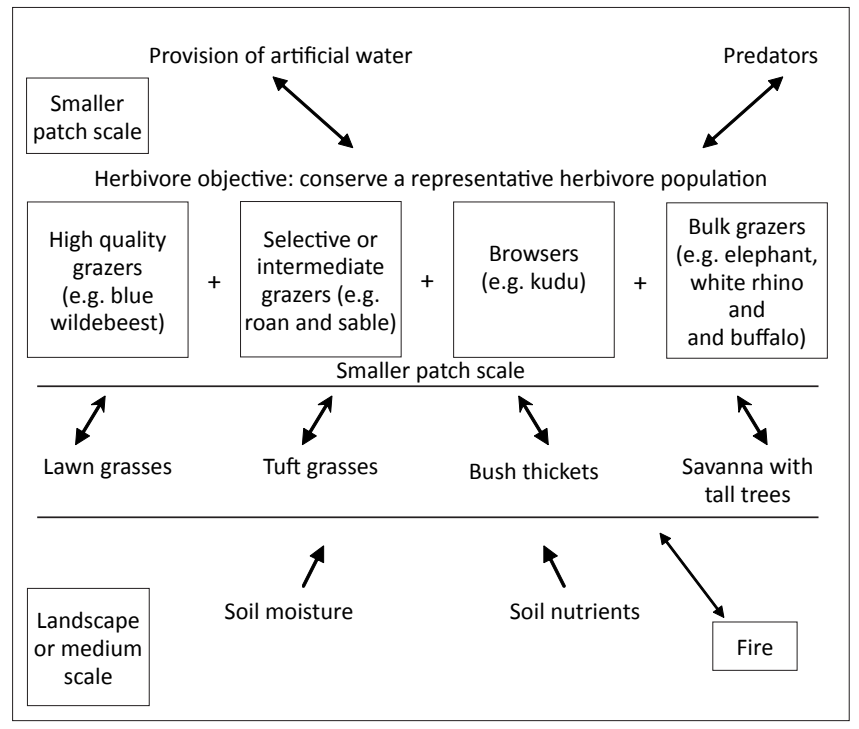

FIGURE 2: An illustration of the interaction between herbivores and the ecological influences of soil moisture and nutrient distribution at the medium or landscape scale. At smaller spatial and temporal scales, soil moisture and nutrients interact with other factors such as water distribution and predators to affect herbivore population and distribution.
Larger-scale heterogeneity may be created by herbivores preferentially utilising areas around natural water sources in the absence of additional artificial sources (Fuhlendorf \& Engle 2001). Similarly, fires that burn over large areas may limit the area covered by lawn grasses by drawing animals away from these areas and thus allowing the areas to change back into areas dominated by tuft grasses (Archibald 2008). However, fires that cover smaller areas can increase the heterogeneity of herbaceous vegetation created by grazers (Archibald et al. 2005; Staver et al. 2009) by increasing the difference in biomass between heavily grazed lawn grass with burnt patches and ungrazed, unburnt patches (Fuhlendorf \& Engle 2001). Although the expectation is that protected areas have to be large to maintain high biodiversity, evidence suggests that this type of habitat heterogeneity can counterbalance the effect of small property size (Cromsigt, Prins \& Olff 2009).

\section{The adaptive management approach Defining the desired state or outcomes of herbivore management}

\section{Economic objectives}

To be able to manage effectively, the objectives of the protected area must be clearly stated. For national parks the preservation of representative biodiversity is the highest priority, as stated in the SANParks vision. For private protected areas economic return through tourism is often the highest priority, whilst for smaller national parks, biodiversity may be less important than the preservation of a particular community or species. The ideal for both types of reserve would be high species diversity and high income. This is not always achievable, for either private protected areas or national parks, as illustrated in Figure 3. In this example, protected areas were scored on the basis of their potential to accrue income through ecotourism (occupancy rates), game sales and hunting as a function of animal diversity. Animal diversity values were derived from the annual game counts and subsequent calculations of stocking density based on the vegetation condition in the form of grass species composition and standing crop, specifically (Peel et al. 2005). The allocated indices for private protected areas and national parks are illustrated in Table 1 and Table 2, respectively.

According to the classification of the 24 private protected areas evaluated, $52 \%$ were classified as having low vegetation potential and low income, $4 \%$ as having high vegetation potential and low income, $30.4 \%$ as having low vegetation potential and high income and only $14 \%$ in the most desired quadrant of having high vegetation potential and a high income bracket (Figure 3a). In 20 national parks managed by SANParks (before the establishment of the Garden Route National Park, where biodiversity is the main priority, 30\% had low diversity and low income, $5 \%$ had high diversity and low income, $45 \%$ had low diversity and high income and 20\% achieved the desired combination of high diversity and high income (Figure 3b). Although these results are preliminary, they illustrate how important the top-down drivers, dictated 

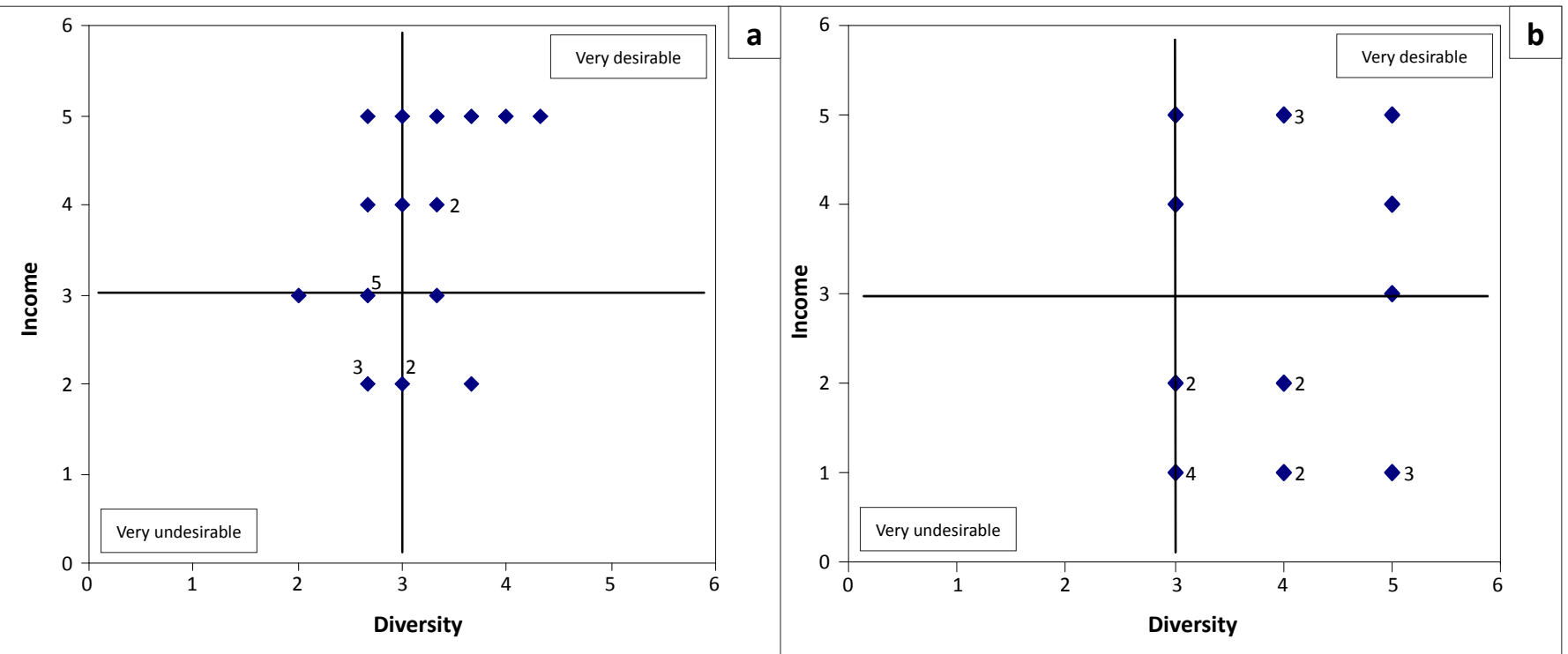

FIGURE 3: Indices of potential income based on (a) product versus vegetation condition parameters and herbivore biodiversity for the private protected areas and (b) on bed nights sold per area $\left(\mathrm{km}^{2}\right)$ per year versus biodiversity parameters (as shown in Table 2). Number next to point indicates number of properties or parks represented with this index where more than one falls into the specific category.

TABLE 1: Indices for biodiversity and income derived for the private protected areas (also see Figure 3a).

\begin{tabular}{|c|c|c|c|c|c|c|c|}
\hline \multirow{2}{*}{$\begin{array}{l}\text { Protected areas } \\
\text { Income }\end{array}$} & \multirow[b]{2}{*}{ Maximum occupancy } & \multirow[b]{2}{*}{ Percentage of maximum occupancy } & \multicolumn{4}{|c|}{ Index } & \multirow[b]{2}{*}{5} \\
\hline & & & 1 & 2 & 3 & 4 & \\
\hline & $65 \%$ & Recorded occupancy /65*100 & $0-10$ & $20-25$ & $26-50$ & $51-75$ & $>75$ \\
\hline
\end{tabular}

\begin{tabular}{|c|c|c|c|c|c|c|c|}
\hline \multirow[t]{2}{*}{ Vegetation composition } & Maximum perennials & Composition index & 1 & 2 & 3 & 4 & 5 \\
\hline & $80 \%$ & $\begin{array}{l}\text { Percentage perennials - max percentage } \\
\text { perennials } / \text { max } \% \text { perennials }\end{array}$ & $0-10$ & $11-25$ & $26-50$ & $51-75$ & $>76$ \\
\hline \multirow[t]{2}{*}{ Biomass } & Max biomass & Biomass index & 1 & 2 & 3 & 4 & 5 \\
\hline & $4453 \mathrm{~kg} / \mathrm{ha}$ & Recorded biomass/max biomass*100 & $1-25$ & $26-50$ & $51-75$ & $76-99$ & 100 \\
\hline \multicolumn{3}{|l|}{ Final diversity index } & \multicolumn{5}{|c|}{ Average index score for all three diversity components } \\
\hline
\end{tabular}

Final diversity index Average index score for all three diversity components

$\mathrm{kg} / \mathrm{ha}$, kilogram per hectare

a, calculation for each index is illustrated in the table with the value between 1 and 5 .

TABLE 2: Indices used to plot income against biodiversity for all parks managed by SANParks.

\begin{tabular}{lll}
\hline Index & Income index & Biodiversity index \\
\hline 1 & $0-40$ & Scenic park with a few herbivore species \\
2 & $40-80$ & Large predators and herbivores present \\
3 & $80-120$ & Vulnerable or endemic species or part of a transfrontier park \\
4 & $120-160$ & Endangered animal and/or plant species or recognised biodiversity hotspots \\
5 & $>160$ & Endangered plant or animal species or endangered community or biodiversity hotspots \\
\hline SANParks, South African National Parks; R/km2, South African rands per square kilometre.
\end{tabular}

SANParks, South African National Parks; R/km2, South African rands per square kilometre.

by the value systems (shown in Figure 1), are in herbivore management.

\section{Biodiversity objectives}

The biodiversity aspect of the objective of SANParks is to maintain biodiversity in all its natural facets and fluxes. Heterogeneity is assumed to be the ultimate source of biodiversity and is also the key link between structure and function(Grant et al.2011;Pickett, Cadenasso \& Benning 2003). Heterogeneity has therefore been used to predict (Murwira 2003; August 1983) and understand (Cromsigt \& Olff 2006) animal distribution. To achieve this ecosystem objective it is necessary to develop an integrated understanding of ecosystem diversity and dynamics and, where necessary, intervene with appropriate strategies, in order to conserve and restore heterogeneity, terrestrial biodiversity and natural processes such as herbivory.

\section{Herbivory objectives}

With recognition of the importance of spatial and temporal variation to maintain ecosystem processes, herbivores are managed primarily as ecosystem drivers and management is considered only where the impact is considered excessive. The approach to strategic adaptive management (Roux \& Foxcroft 2011) is used to learn about herbivore-vegetation dynamics. This approach strives to allow herbivory to bring 
about sufficient ecosystem change or flux whilst providing a safety net to avoid unacceptable or irreversible change to the vegetation and associated faunal communities of the ecosystem. Larger protected areas are usually better able to represent a wider range of different states than smaller areas; however, some degree of change is recognised as desirable even in smaller parks.

\section{Indicators of not achieving herbivore objectives Vegetation changes}

One of the most important indicators of excessive herbivore impact is vegetation homogenisation due to overutilisation, rather than creating the heterogeneity as is expected of herbivory in natural systems (Adler et al. 2001; Asner et al. 2009; also see Grant et al. [2011] for a discussion on evaluating heterogeneity as an indicator of the desired state). Changes in the structure of vegetation (especially woody plant species) in savannas may have a significant effect on other dependent species by, for example, altering nesting and perching sites for birds, reptiles and bats (Cumming et al. 1997), forage for browsers (Skarpe et al. 2004; Woolnough \& Du Toit 2001) and habitat for different herbaceous species (Scholes \& Archer 1997). Furthermore, large trees (more than $5 \mathrm{~m}$ tall) have been shown to play an important role in ecosystem functions such as hydraulic lift (Ludwig 2001), erosion control on river margins (Rogers \& O'Keeffe 2003) and nutrient cycling (Treydte et al. 2007). Mixed feeders, especially elephants, are known to be an important driver of shifts in vegetation structure and composition as they forage selectively at specific height classes (Guldemond \& Van Aarde 2007; Ihwagi et al. 2010; Kerley \& Landman 2006; Shannon et al. 2008). Changes in vegetation structure can also be caused by giraffe (Bond \& Loffell 2001) and porcupine (Yeaton 1988), as well as by nonherbivore factors such as high winds, disease, floods (Rogers \& O'Keeffe 2003) or drought (Viljoen 1995; Shackleton 1998).

Herbivore impact has classically been measured according to vegetation outcomes, which are mainly aimed at avoiding degradation (Scholes 2009). Degradation can be described as the reduction in capacity of the vegetation or soil to support life through the damage of physical, chemical or biological properties, thereby contributing to an unsustainable ecological system (Vlek, Le \& Tamene 2008).

Overgrazing (which is a function of time and not necessarily a function of animal number) is a concern because it can lead to a degradation of the herbaceous layer. This can be defined as the inability of forage species to maintain themselves over time due to an excess of herbivory and related processes (Mysterud 2006). This is a result of a weakening of the grass layer, resulting in reduced root growth and eventually reduced rainfall infiltration (Snyman 2009), increased run-off leading to soil erosion and a loss of soil nutrients (McGinty, Smeins \& Merril 1979; Van de Koppel et al. 2002). The major indicator of such degradation is a loss of the generally palatable and productive perennial grasses, which further results in a decrease in herbaceous basal cover. This is further reflected as a long-term reduction in both aboveground (Diaz, Noy-Meir \& Cabido 2001), and below-ground (Snyman 2005) net primary production.

Another indicator of excessive herbivore impact is an increase in tree density as a result of their deeper rooting systems, which allow them to access deeper water resources and thus facilitate a cohort of trees to emerge when the basal cover is decreased and grass competition is removed. Increases in tree density are exacerbated by a reduced frequency of high-intensity fires as a result of the weakened grass layer, which allows fire-sensitive woody saplings to establish (Scholes 2003). Conversely, high fire frequencies may result in the proliferation of unpalatable, fire-tolerant grasses such as Bothriochloa radicans. Certain woody species are also known to increase in response to high levels of herbivory independent of the change in fire history, especially in more arid areas (Scholes \& Archer 1997; Ward 2005).

\section{Herbivore numbers and distribution}

Herbivore numbers are seldom a concern in large parks where flux is required to maintain system heterogeneity; however, herbivore numbers are often used as an indicator in smaller parks and protected areas to avoid possible undesirable change (Peel et al. 1999). The only instance where larger parks would be concerned about herbivore numbers is in the case of a decline of a specific group of herbivores. The decline in the selective grazers in the KNP is such an example, because the decline indicates unacceptable ecosystem changes (Grant et al. 2002; Ogutu \& Owen-Smith 2003; Owen-Smith 1985). An alternative approach in smaller parks and private protected areas is to evaluate animal numbers against the forage available to optimise for economic purposes within a sustainability paradigm.

A change in herbivore distribution is an alternative indicator of herbivory, for example the change in elephant distribution following the closure of waterpoints in the KNP (Smit \& Ferreira 2010). Herbivore impact may be expected to be evident first in favoured habitats, such as those with high nutritional resources like sodic sites and termite mounds (Botkin, Mellilo \& Wu 1978; Grant \& Scholes 2006; Naiman et al. 2003; Wentzel, Botma \& Van Rooyen 1991). The absence of unacceptable impact in such areas would be expected to indicate that the less favoured areas would not be undesirably impacted.

\section{Thresholds of potential concern}

An important aspect of adaptive management is setting levels of concern that would indicate that the objectives of the conservation area may not be achieved (Rogers 2003). Thresholds of potential concern (TPCs) can be seen as hypotheses of performance measures that predict management outcomes. Scale is explicitly considered in the setting of each TPC, which is, in turn, determined by the scale at which the specific element of function, structure or composition is relevant in the ecosystem. Ideally, all biophysical TPCs should relate either to the imminent danger 
of loss of a species or to a real transition beyond the desired set of varying conditions (as expressed by the TPCs). These changes usually happen gradually (e.g. the conversion of grassland to woody thickets), but sudden changes have been recorded in other ecosystems such as lakes (Biggs, Carpenter $\&$ Brock 2009). Thus, it is difficult to determine whether a point constitutes a real concern that should lead to management actions and whether the TPC should rather be adjusted as indicated by improved understanding. When a TPC indicates that the management did not have the predicted outcome, the exceedence is discussed with scientists and managers who then decide on appropriate management adjustments. The evaluation of the outcome of the management action is an integral aspect of this process and informs the amendment of the TPC and potential management actions.

Each TPC requires a threshold or benchmark against which to measure change and to guide the setting of a TPC. Such information is not available for most of the indicators and, therefore, the oldest reliable historical data are used as an initial benchmark to be adjusted as knowledge of the system improves. A rate-based approach to setting and evaluating TPCs is probably the best solution at this stage (Scholes \& Kruger 2011). The temporal framework used for TPCs attempts to ensure that future generations still have options of different outcomes.
The TPCs were originally developed to try to detect homogenisation or unacceptable change in:

- structural diversity in the woody and herbaceous component

- patchiness in the woody and herbaceous component

- dominant and subdominant tree species

- basal herbaceous cover

- herbivore species composition

- herbivore distribution

- landscape function (nutrient cycling, infiltration and soil stability, as described by Ludwig et al. [2004]).

Rare species were evaluated separately and the suggested TPCs and monitoring are discussed by McGeoch et al. (2011) Table 3 summarises the specific concerns raised by park managers in science-management forums. The TPCs listed are all preliminary and will be re-evaluated as more knowledge is gained, if necessary.

\section{Monitoring change in vegetation and herbivores}

Effective monitoring is imperative in the adaptive management process. According to Duncan and Wintle (2008) a monitoring programme aimed at determining whether the management objectives are achieved should:

- use clearly defined performance measures (e.g.

TABLE 3: Examples of management concerns and related thresholds of potential concern in national parks in South Africa.

\begin{tabular}{ll}
\hline Park & Concern \\
\hline Addo Elephant National Park & $\begin{array}{l}\text { Vegetation impacts of herbivory: loss of palatable endemic } \\
\text { species }\end{array}$
\end{tabular}
TPC and basis for threshold

Loss of endemic indicator species (Landman, M. \& Kerley, G.I.H., 2009, 'Elephant impacts and potential indicators of elephant-induced change to vegetation composition and structure in Addo Elephant National Park: Baseline assessment of key-plant species in Colchester, Kuzuko Contractual Park and the Darlington monitoring exclosures', Report by the Centre for African Conservation Ecology, Nelson Mandela Metropolitan University, Port Elizabeth)

Addo Elephant National Park Loss of thicket patches resulting in homogenisation

1. When using satellite imagery, the percentage of area of bare ground is more than $25 \%$ of the area covered by thicket clumps

2. Thicket clumps should not be less than $3 \mathrm{~m}$ in diameter and $2.5 \mathrm{~m}$ in average height (based on best available knowledge; to be tested)

\begin{tabular}{|c|c|c|}
\hline Mokala National Park & Overgrazing of open savanna areas & $\begin{array}{l}\text { When the distribution of buffalo changes from a clumped to more even, uniform or } \\
\text { random distribution across the landscape (based on best available knowledge; to be } \\
\text { tested) }\end{array}$ \\
\hline Camdeboo National Park & $\begin{array}{l}\text { Decrease in selected palatable species: indicator species } \\
\text { (herbivory) }\end{array}$ & $\begin{array}{l}\text { A decrease of } 30 \% \text { in the abundance of any one of the listed palatable species over } 3 \\
\text { years (based on best available knowledge; to be tested) }\end{array}$ \\
\hline Camdeboo National Park & Increase in unpalatable species & $\begin{array}{l}\text { An increase of } 40 \% \text { in the abundance of any one of the unpalatable species listed, or } \\
\text { an increase of } 50 \% \text { of the group of unpalatable species over any } 3 \text { years (based on best } \\
\text { available knowledge; to be tested) }\end{array}$ \\
\hline Mapungubwe National Park & Impact of elephant on riverine trees & $\begin{array}{l}\text { When } 10 \% \text { of the dominant riverine trees have lost more than } 50 \% \text { of bark around } \\
\text { their circumference (Acacia nigrescens, Ficus sycomorus, Acacia xanthophloea, } \\
\text { Faidherbia albida) }\end{array}$ \\
\hline Kruger National Park & Change in woody structure & $\begin{array}{l}\text { Reference to the benchmark: a drop of more than } 40 \% \text { in the proportional abundance } \\
\text { of trees less than } 1 \mathrm{~m} \text { tall, or a drop of more than } 10 \% \text { of trees taller than } 5 \mathrm{~m} \text { (based } \\
\text { on best available knowledge; to be tested) }\end{array}$ \\
\hline Kruger National Park & Loss of large trees & $\begin{array}{l}\text { A loss of } 30 \% \text { or more of trees taller than } 5 \mathrm{~m} \text { in the high impact zone or } 5 \% \text { or more } \\
\text { of trees in the low impact zone (based on best available knowledge; to be tested); } \\
\text { impact zones are defined in the KNP management plan (SANParks 2008) }\end{array}$ \\
\hline Kruger National Park & Unacceptable population trend & $\begin{array}{l}\text { Three monotonic drops of more than } 10 \% \text { overall in wildebeest population numbers } \\
\text { in a dry cycle (see Mills, M.G.L., Biggs, H.C. \& Whyte, I.J., 1995, 'The relationship } \\
\text { between rainfall, lion predation and population trends in African herbivores', Wildlife } \\
\text { Research 22, 75-88. doi:10.1071/WR9950075) }\end{array}$ \\
\hline Kruger National Park & Change in herbivore distribution & $\begin{array}{l}\text { A reduction of } 25 \% \text { or an increase in the number of pixels }\left(1 \mathrm{~km}^{2}\right) \text { where a species } \\
\text { occurred, based on historical distribution data }\end{array}$ \\
\hline Private protected areas & $\begin{array}{l}\text { Number of grazers that can be supported by the available } \\
\text { forage }\end{array}$ & $\begin{array}{l}\text { When there is not sufficient forage to sustain current animal biomass (based on } \\
\text { existing knowledge of metabolic requirements) }\end{array}$ \\
\hline Private protected areas & $\begin{array}{l}\text { Energy requirements of grazers not met by energy available } \\
\text { from the forage }\end{array}$ & $\begin{array}{l}\text { When the energy required per day for maintenance, production, locomotion and } \\
\text { predator avoidance exceeds available forage }\end{array}$ \\
\hline
\end{tabular}

TPC, threshold of potential concern; KNP, Kruger National Park; m, 1 metre; $\mathrm{km}^{2}$, 1 square kilometre. 
population size of forest dependent species)

- adequately reflect the precision (confidence) requirements implied by the management objectives

- be performed at a spatial extent and resolution congruent with the management objectives

- avoid covering too many aspects

- target indicators for which risk assessments can be undertaken.

Historically, monitoring in the national parks and protected areas has focused mainly on the herbaceous vegetation and herbivore numbers. In the KNP, vegetation monitoring was primarily aimed at informing fire management (Trollope 1990a), whilst in the private protected areas monitoring was aimed at determining the available forage. This information was used to determine the number of animals that could be supported by the forage resources without deterioration of the vegetation due to herbivory. This applies in particular to grazers, as grass appears to be more limiting than browse in most instances (Peel et al. 1999).

In the KNP an extensive vegetation monitoring programme was initiated in 1989 with 533 sites across the entire park (approximately 2 million hectares), with the primary intention of guiding fire regimens and, secondly, to assess vegetation change in response to herbivory (Trollope 1990b). This programme was expanded to include the woody component in 2002 (Zambatis 2002). Herbaceous species surveys were performed annually by rangers whilst the woody component was monitored every 3 years. Additionally, fixed-point photography sites and aerial photography have been used as vegetation monitoring tools (Eckhardt, Van Wilgen \& Biggs 2000). Detailed vegetation maps have been developed for all the national parks and the private protected areas adjacent to the KNP (Bezuidenhout 1996, 2004; Bezuidenhout \& Brown 2008; Gertenbach 1983; Gotze et al. 2008; Peel, Kruger \& MacFadyen 2007; Peel et al. 2005; Rubin 1998; Rubin \& Palmer 1996; Siebert \& Eckhardt 2008; Van Rooyen et al. 2008; Van Staden \& Bredenkamp 2006; Venter 1986; Venter et al. 2003). These studies are valuable to define monitoring sites and can contribute valuable baseline data to detect future trends. Herbivore exclosures, erected in several parks to monitor vegetation change due to herbivory, are also valuable reference sites (Asner et al. 2009; Blose 2007; Landman \& Kerley 2009; Siebert \& Eckhardt 2008) and have played an important role in understanding elephant impacts in Addo Elephant National Park (Lombard et al. 2001).

In the KNP, large mammals have been counted annually from 1977 to 1994 using a fixed-wing aircraft (Redfern et al. 2002). Since 1998, the census has been carried out along fixed transects, thus allowing for the precision of the census to be determined (Bothma et al. 1990; Peel \& Bothma 1995). In most of the other national parks and private protected areas large mammals are counted annually.

The ARC-API Savanna Ecosystem Dynamics project was set up in 1989 and covers an area of some 450000 ha of the eastern Lowveld, between the Sabie and Letaba Rivers on private protected areas adjacent to the KNP. It includes 700 vegetation sampling sites, which are monitored annually with the aim of detecting vegetation change over time. The database includes environmental (e.g. rainfall) and management (e.g. animal numbers) data as well as a faecal analysis component as an adjunct to the vegetation monitoring. An aerial animal count component includes animal type, number and distribution, with data going back to 1992. The field work of this project is carried out by trained technicians.

\section{Evaluation of thresholds of potential concern}

\section{Vegetation}

In the KNP one of the main concerns around vegetation change has been the loss of large trees (Coetzee et al. 1979; Eckhardt et al. 2000; Grant et al. 2007). It is acknowledged that a rate-based TPC is the ideal approach to evaluate rate of loss of large trees and data are presently being collected to develop such a TPC. Seedling survival and recruitment to the taller tree class will be included in such a TPC and are being addressed by research projects. At this stage the best available data to evaluate the TPC are those of the Veld Condition Assessment woody survey. The data, collected in 2006, were used to determine whether the large tree threshold had been exceeded. Vegetation survey data of 1957 (when the experimental burn plots were created as described by Van Wilgen et al. 2011) were used as the benchmark. Only landscapes with burn plots (Van Wilgen et al. 2007) could be evaluated. The Pretoriuskop landscape, situated in a highrainfall area showed an increase in tall trees, but the decline was much more than the maximum allowed for the low impact zones in the three other major landscapes (Table 4).

To inform appropriate management action the mechanism driving the loss of large trees must be determined. The distribution of elephant suggests that most impact is at a small scale and concentrated along the main perennial and seasonal rivers (Smit \& Ferreira 2010). The monitoring was thus adjusted to include trees along these rivers in the KNP (Druce et al. 2008; Hartmann 2009). In an attempt to mitigate these trends, management actions included an attempt to decrease the frequency and intensity of fires in the areas of concern as well as to investigate methods of decreasing elephant density and utilisation in these areas, as guided by the elephant management plan (SANParks 2010).

TABLE 4: Selected landscapes indicating the threshold of potential concern for loss of large trees (more than 5 metres), the benchmark and the subsequent survey data.

\begin{tabular}{lllll}
\hline Landscape & TPC for percentage decline & Benchmark (trees/ha 1954) & Monitoring (trees/ha 2006) & Percentage decline \\
\hline Mopanie: northern basalts & 10 & 20 & 3 & $85 \%$ \\
Satara: central basalts & 10 & 26 & 7 & $73 \%$ \\
Skukuza: southern granites & 10 & 83 & 3 & $96 \%$ \\
Pretoriuskop: high-rainfall granites & 10 & 47 & 55 & $-14 \%$ \\
\hline
\end{tabular}

TPC, threshold of potential concern; trees/ha, amount of trees per hectare. 
Data collected annually during surveys on private protected areas adjacent to the KNP illustrate the use of rate of change as a TPC (Figure 4). The proportion of trees in different height classes impacted by elephant is illustrated in Figure 5 to evaluate the possible use of impact TPCs. The latter is monitored to determine whether the tree layer is tending towards domination by a single height class (homogeneity), which is problematic with regard to both the biodiversity and sustainability objectives.

More detailed information from private protected areas can assist in evaluating elephant impact as a mechanism for change in woody composition and structure. An exploratory linear regression (Figure 4a) indicates that the density of trees taller than $5 \mathrm{~m}$ in protected area 1 has declined markedly since 1992 corresponding to an increase in elephant densities. The decline was slow initially $\left(R^{2}=0.54\right.$ until 2000), but then became more rapid $\left(R^{2}=0.76\right)$. The overall regression coefficient was $R^{2}=0.67$. This is similar to the trend recorded in the KNP (see earlier) and indicates that elephant utilisation is an important mechanism for the loss of large trees. For protected area 2 (Figure 4 b) the increase in elephant numbers was slower and decreased when the elephant moved out of the area recently $\left(R^{2}=0.54\right)$. The impact is influenced by rainfall as indicated by the decline in taller tree densities in dry years (1989-1990, 1993-1994 and 1998-1999). There is some indication of an increase in the density of trees taller than $5 \mathrm{~m}$ in protected area 2 , which may be related to a recent efflux of elephant from the area. Together this may indicate that taller trees may be recruited if the elephant density is reduced.

As shown in Figure 5, the selection for height classes demonstrate a clear selection for trees between $2 \mathrm{~m}$ and $5 \mathrm{~m}$ tall, and those taller than $5 \mathrm{~m}$. These results show that the loss of large trees can be effectively monitored using existing monitoring techniques and that TPC exceedences can be associated with elephant impact.

Change in species and community composition was examined as an indication of elephant impact in the Marakele National Park (MNP). During 1996, 15 monitoring plots were subjectively placed in the major vegetation communities in the MNP. At that stage the park was dominated by a mountainous area with a very small area of footslopes and plains and the recommendation was to introduce 15 elephants. In 1996, however, 39 elephants were reintroduced. The point-centred quadrate method of Coetzee and Gertenbach (1977) was adapted to monitor the impact of elephants on the vegetation using randomly distributed plots in four of the major plant communities identified as possible suitable elephant habitat in the MNP (Van Staden \& Bredenkamp 2006).

Monitoring was initiated in March 1996 before the elephants were introduced and repeated during the next 2 years, with a subsequent follow-up in October 2008. A higher diversity of plant species was recorded in the different plant communities owing to the opening of gaps in the plant communities, but there was a negative impact on the microhabitats of the thicket and forest, which exposed rare and endangered species.

\section{Herbivore threshold of potential concerns}

Several herbivore TPCs have been developed for the KNP. However, the only TPCs that were addressed were the declines in and retraction of the distribution of the lower density antelope and the increase in elephant numbers. The TPC developed for detecting unacceptable decreasing trends in the low density antelope resulted in the creation of an additional breeding enclosure (Grant \& Van der Walt 2000). This TPC was later supplemented with nutritional status TPC, meant to flag unacceptable low nitrogen and phosphorus concentrations in the faeces of roan antelope (Hippotragus equinus). These TPCs were replaced by the TPCs for species of concern as addressed by Rebelo et al. (2011). The effect of the increase in elephant is measured using the impact TPCs as discussed above.

\section{Changes in herbivore population}

In smaller national parks and private reserves, there are often concerns about declining herbivore populations. Based on the data collected from the private protected areas, Figure 6 shows a monotonic decline of blue wildebeest, which exceeds the guideline TPC that was set at three monotonic drops of 10\% (also see Table 3).

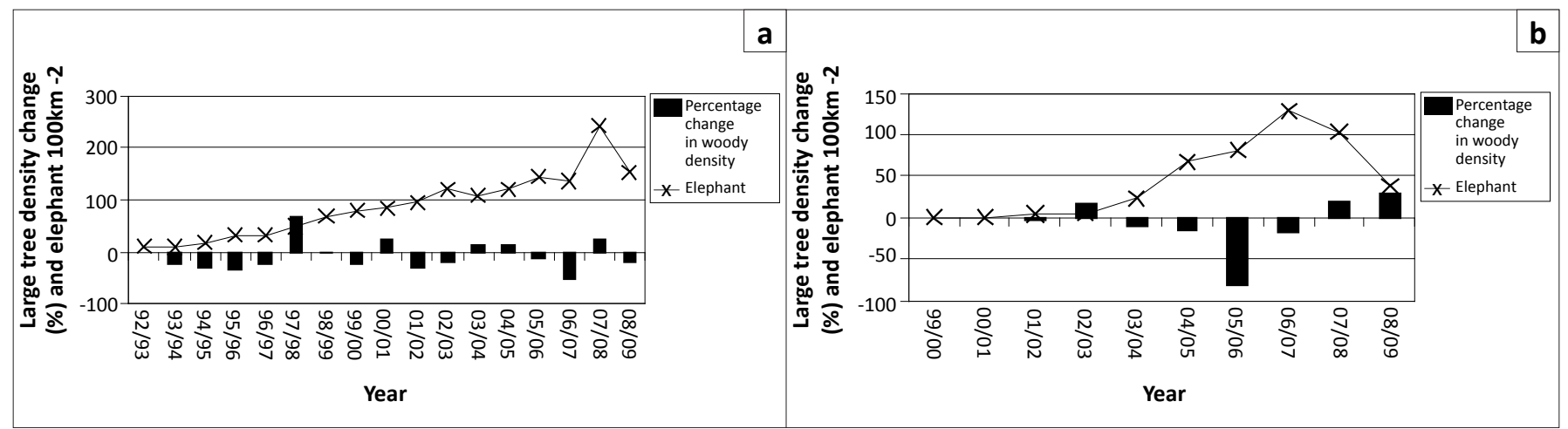

FIGURE 4: The annual percentage change in trees taller than 5 metres (a) compared to an increasing trend in elephant density in one of the private protected areas and (b) compared to a variable trend in elephant density in a private protected area. 


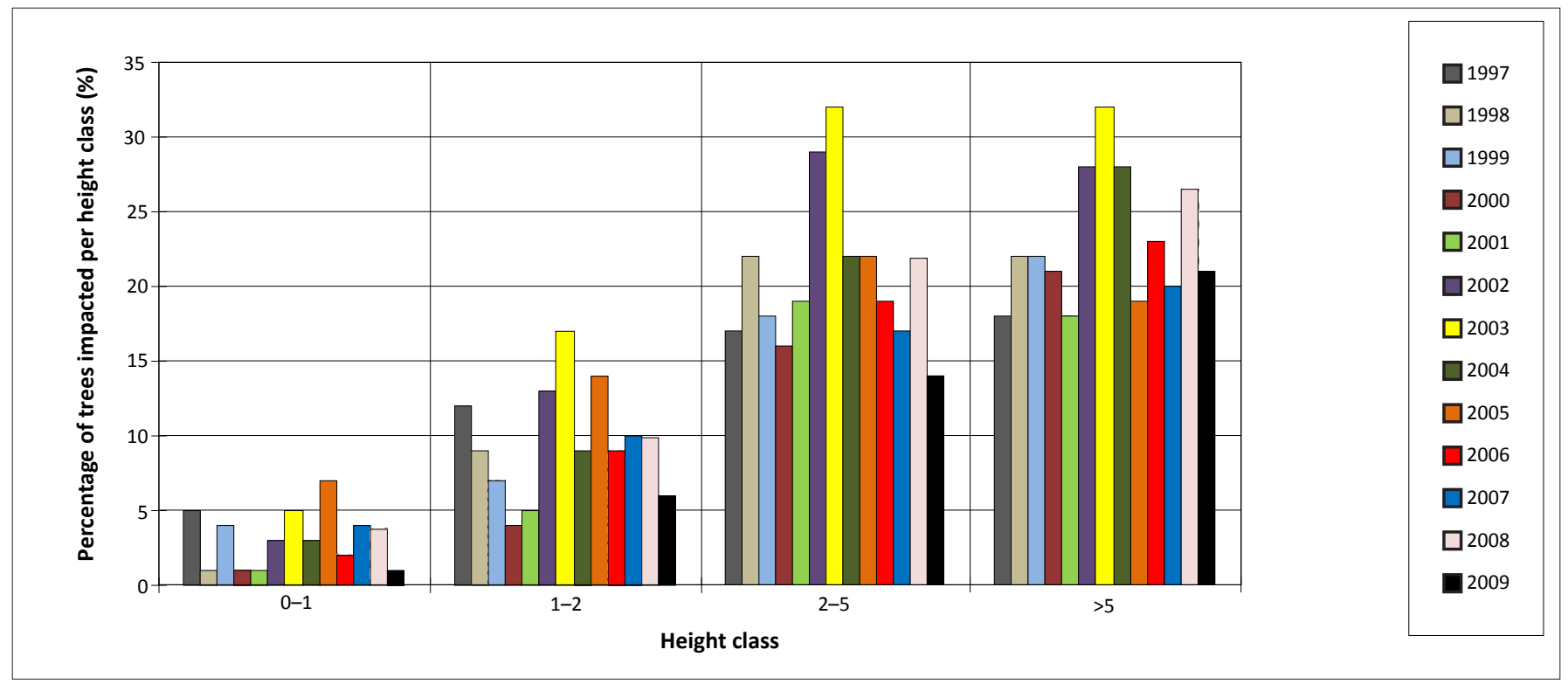

FIGURE 5: The proportion of trees of different height classes utilised by elephant.

\section{Alternative approaches to monitoring?}

\section{Site selection}

Acknowledgement of the importance of evaluating a loss of heterogeneity at a large scale as an indication of system change, allows changes at smaller scales to be addressed using a step-wise approach (Figure 7).

In the model shown in Figure 7, monitoring is focused on areas or habitats where a particular concern is most likely to be exhibited by, for example, nutrient hotspots for grazers or large trees for elephants. Unacceptable change in a predetermined sample of selected sensitive and key habitats should then trigger a more detailed and expanded monitoring programme in the area of concern to confirm the TPC exceedence. The thresholds set at $60 \%$ are only illustrative and should be determined by experts if sufficient data are not available to determine the TPC. Such a TPC should reflect not only unacceptable changes due to excessive impact but also a lack of impact that would lead to a loss of, for example, high-nutrient areas such as grazing lawns, which would decrease nutrient availability and habitats used to avoid predation. These areas could be selected for focused monitoring as most grazer populations rely on relatively small areas of key resources (Grant \& Scholes 2003; Hanley 1982; McNaughton et al. 1989; Stock et al. 2009). Examples of such nutrient hotspots for grazers are sodic sites, termite mounds, calcrete hard pans and grazing lawns (Grant \& Scholes 2006; Mutanga et al. 2004; Naiman et al. 2003; Schmitz 2008; Stock et al. 2009; Traill 2004; Treydte et al. 2008), whilst browsers tend to concentrate in riverine areas and within specific vegetation types. Elephants also prefer trees of a certain height class (Shannon et al. 2008) and more focused monitoring of this class may detect unacceptable trends in the loss of large trees.

\section{Alternative thresholds of potential concern}

We contend that there will be almost no risk of unacceptable herbivore impact as long as these intensely utilised patches are not overutilised (Gordon et al. 2004; Van de Koppel et al. 2002). These areas could therefore be used as indicators of herbivore impact (Muller 2005). If plants in these areas are grazed too frequently, composition may change with a concomitant reduction in grass tuft size and basal cover, resulting in an increase in the area of bare soil (Senft et al. 1987). This is more likely to happen in arid and semiarid environments (Mysterud 2006) and a bare ground index may be a useful TPC for intensely utilised grazing areas in areas with an annual rainfall of less than $650 \mathrm{~mm}$ (Sankaran, Ratnam \& Hanan 2004). In more mesic systems (rainfall > $650 \mathrm{~mm}$ ), overgrazing may lead to replacement of palatable species by unpalatable species, and the abundance of the latter as well as the ratios of annual to perennial grasses may therefore be more useful TPCs. Species composition and biomass may also be an indicator of a decline in grazer numbers, which could result in a change in the herbaceous structure, with lawn grass areas giving way to tuft grass areas (Archibald 2008).

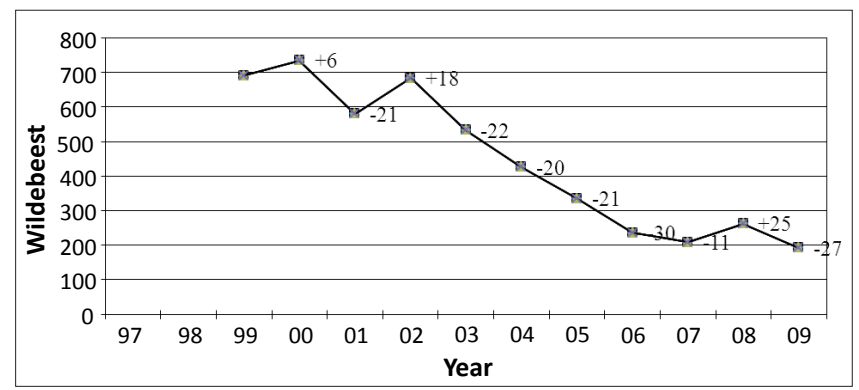

FIGURE 6: Decline in the blue wildebeest population in a private protected area between 1997 and 2009 (figures indicate percentage decline per year). 


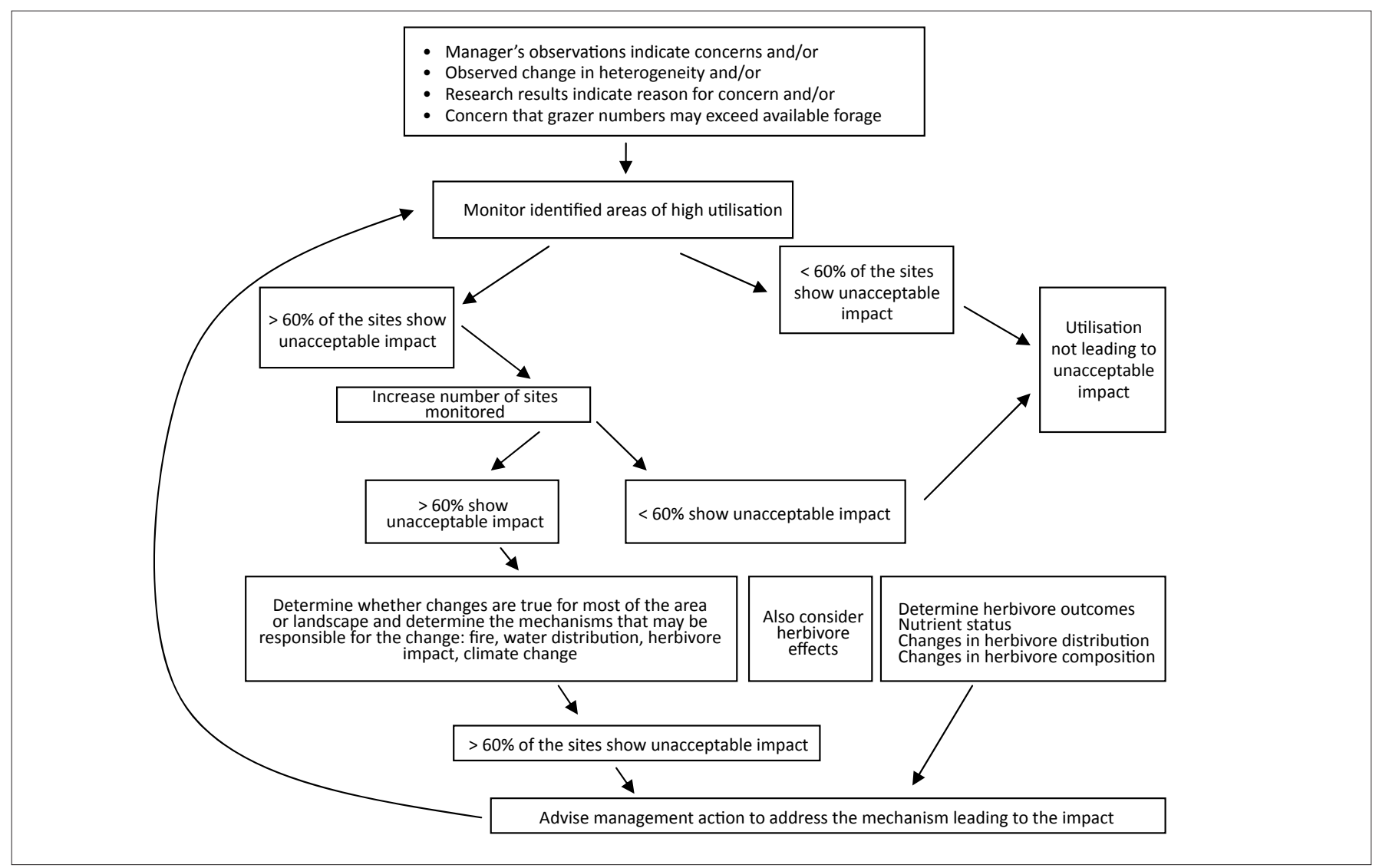

FIGURE 7: A framework for structuring a monitoring programme for detecting vegetation change and feedback mechanisms; thresholds set at $60 \%$ are illustrative only.

\section{Animal condition and nutritional status}

In smaller conservation areas there is often a concern about the loss of herbivores due to a lack of forage resources. Forage resources could thus reflect a deleterious change in vegetation and should be considered when management decisions are taken. A decline in the condition of herbivores due to declines in the amount of preferred forage and foraging areas (Cromsigt et al. 2009) may thus be an indication of insufficient resources. This is reflected as a decline in phosphorus and nitrogen concentrations in faeces (Dörgeloh, Van Hoven \& Rethman 1998; Grant et al. 2000). Nitrogen and phosphorus concentrations in dry faeces below the threshold values of $1.2 \%$ and $0.25 \%$, respectively, would constitute a TPC exceedence (Grant et al. 2000; Wrench, Meissner \& Grant 1997). Such a TPC may also be useful for management of rare species, which require more intensive management, and if there are concerns about the loss of such species.

For selected species, a TPC that indicates a change in distribution may be valuable. An example is the change in elephant distribution away from rivers in the KNP (Young, Ferreira \& Van Aarde 2009b), which is probably associated with an increase in elephant density. At larger scales a change in the system may be reflected by the existing range contraction TPC, as was exhibited by the roan antelope in the KNP (Harrington et al. 1999).

\section{Energy flows and sustainability}

In smaller parks and private protected areas managers prefer to use a precautionary approach to avoid overutilisation and degradation based on carrying capacity. Coe et al. (1976) use energy flows based on rainfall and vegetation biomass as a TPC, rather than population numbers according to a predetermined carrying capacity. Another approach to this is to use requirements for endosomatic energy (food and work) as a TPC (Peel 2005). In this case the average energy demands of the different species are based on an estimate of the activity patterns, which affect the feeding requirements of the various species. Available energy is determined by subtracting the energy fraction that is reduced by internal overheads (e.g. consumption used to maintain the population) and external overheads (e.g. predation that reduces the population) from the useful energy flows available from the forage (Peel 2005). Environmental loading (the biophysical cost of the diet) is used as an indicator of the forage energy that is available to the animals. It is calculated using the metabolisable energy of the forage (10.5 MJ/kg dry matter). Estimates vary from $22 \%$ to $49 \%$ in the broad-leaved savannas to between $15 \%$ and $80 \%$ in fine-leaved savannas (in highly nutritious systems). In this case, the TPC would be a conservative estimate of the forage energy available that would avoid the loss of grazing animals and a concomitant degradation of the grazing resource. This more precautionary approach may be suitable in smaller national parks and wildlife reserves where fluctuations 
have to be limited because of the scale and limited habitat heterogeneity of the area. Figure 8 illustrates the process taken from a private protected area adjacent to the KNP where the resource is not limiting for the period in question.

\section{Economic return}

Managers of conservation areas tend to avoid issues surrounding economics, but economic return is an integral part of herbivore management. This suggests that a TPC is required that would define the desired position of the enterprise relating to biodiversity and economy (Figure 3).

\section{Discussion}

Rangelands have long been managed using animal numbers as an indicator of degradation related to excess herbivory (Fynn \& O'Connor 2000; O'Reagain \& Turner 1992; Scarnecchia 1988). Using vegetation change as an indicator of the impact of herbivory is a well-explored field and has also been used to determine the impact of wild herbivores (Trollope 1990a; Peel et al. 2005). However, by acknowledging the importance of flux and heterogeneity in complex systems, the management of large conservation areas such as the KNP and the Kgalagadi National Park have moved to using animal impact and other indicators (e.g. a measure of heterogeneity) to inform management rather than animal numbers (Grant et al. 2011). Private conservation areas achieve their desired state by ensuring sufficient income from their enterprises by avoiding loss of animals due to a lack of forage resources; in other words a sustainability paradigm. The concern about herbivore management is thus focused on impacts and responses rather than numbers. To measure impacts reliably we need to have some predictive understanding of the response of different herbivores to changes in climate or soil (template) and the related vegetation as well as the response of the vegetation to herbivory. Predators, disease and water provision all impact on the way that herbivores utilise the landscape and these factors need to be considered if we are to predict and understand herbivore impacts on their environment (Young, Ferreira \& Van Aarde 2009a). The TPCs developed for the KNP attempted to address the outcomes of this complex system according to vegetation composition and structure, and herbivore populations and distribution.

We have evaluated some of the TPCs to determine how useful they would be in practice and although some need to be adjusted, they have proved useful for flagging concerns. The importance of understanding the mechanisms that lead to the TPC exceedence was emphasised and should be considered when designing monitoring programmes.

The suggested use of energy flows to determine appropriate animal numbers in smaller protected areas shows great promise. Using this method, animal type and number can

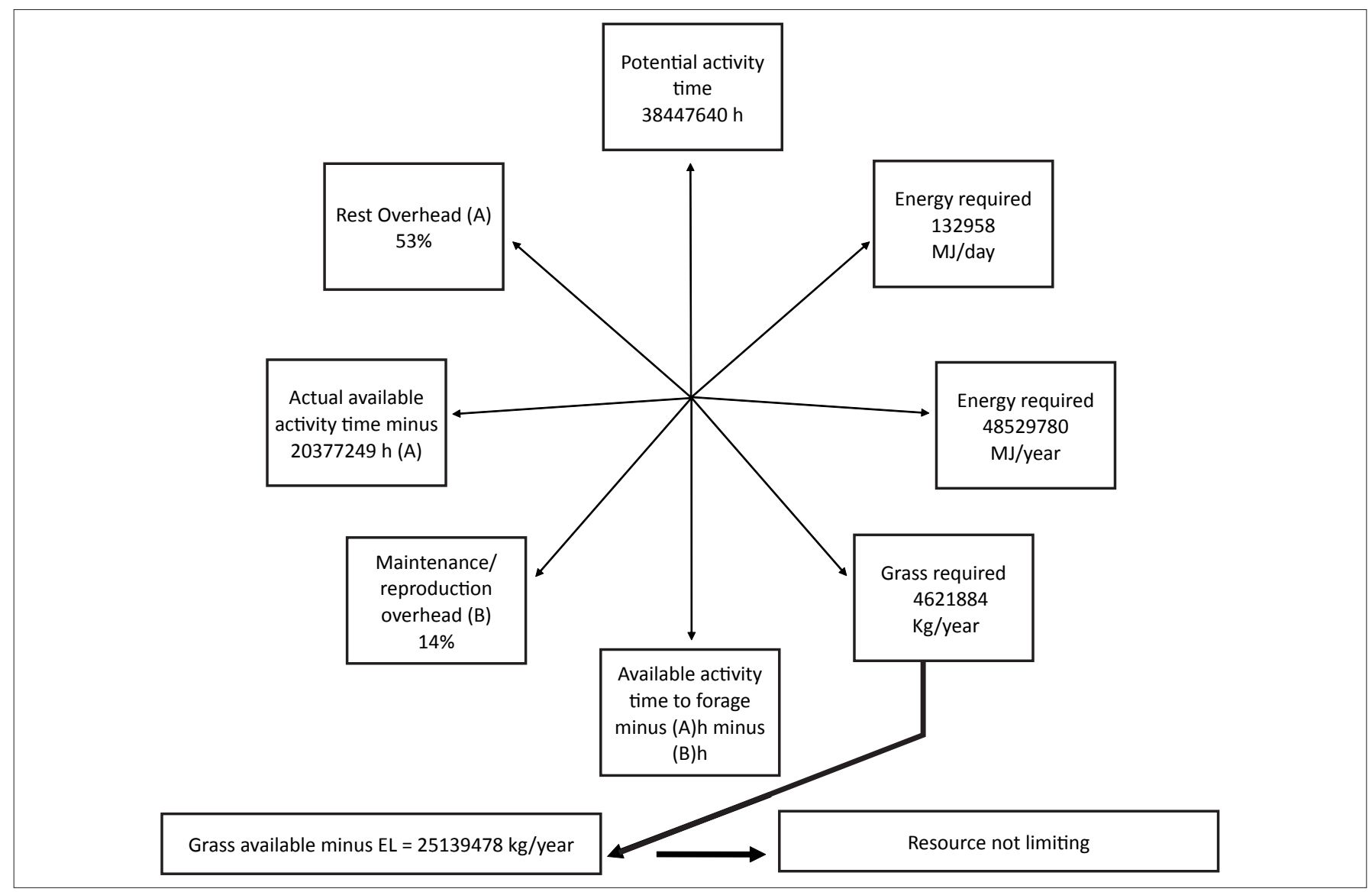

$\mathrm{EL}$, environmental loading; $\mathrm{kg} /$ year, kilograms per year; MJ/year, megajoules per year; $\mathrm{h}$, hour.

FIGURE 8: The capacity of the grazing resource, presented as the amount of grass required versus that available to provide sufficient energy to a game population of known number. 
TABLE 5: Summary of the drivers that may be responsible for exceedences of thresholds of potential concern. A tick indicates that the driver may influence this vegetation response and should therefore be associated with monitoring for the specific driver.

\begin{tabular}{lllll}
\hline Driver & Structural change & Compositional change & Degradation as increase in bare soil & Herbaceous biomass \\
\hline Fire & $\mathrm{V}$ & $\mathrm{V}$ & $\mathrm{V}$ & $\mathrm{V}$ \\
Mega-herbivores & $\mathrm{V}$ & $\mathrm{V}$ & $\mathrm{V}$ & $\mathrm{V}$ \\
Grazers & $\mathrm{V}$ (herbaceous layer) & $\mathrm{V}$ & $\mathrm{V}$ & $\mathrm{V}$ \\
Rainfall & - & $\mathrm{V}$ & $\mathrm{V}$ (due to shading out of grasses) & $\mathrm{V}$ \\
Increase in $\mathrm{CO}_{2}$ & $\mathrm{~V}$ (increase in woody layer) & $\mathrm{V}$ & & $\mathrm{V}$ \\
\hline
\end{tabular}

$\mathrm{CO}_{2}$, carbon dioxide.

be manipulated in response to vegetation biomass and habitat change. This approach requires sophisticated data and knowledge, but will allow more accurate estimations of the number of animals that can be sustained by the system. Using such an approach will allow more natural flux than the fixed 'carrying capacity' approach that has been used in the past.

To be able to reflect changes that may be of concern, monitoring must address specific questions for each component at each relevant scale. This is a daunting task for conservation agencies with limited resources and a much more focused approach is thus recommended. To prioritise monitoring efforts it is necessary to identify the main drivers of vegetation change as well as the types of change that may be expected. Table 5 is an attempt to list the most important drivers in the savanna parks and the vegetation changes that could be expected as an outcome of the effects of each of these drivers.

Where resources for monitoring are limited, we suggest that the most sensitive indicators of the expected change be the focus of the monitoring programme. The selected sites should be those that are most likely to be vulnerable to change. Once a concerning change at the selected sites is detected, surveys should be expanded to more sites to confirm the trend. Knowledge of the mechanisms that lead to these concerning changes is important in informing possible management action. Exclosures that are managed differently from the surrounding areas could act as reference points in large protected areas. This more focused approach needs to be tested and evaluated to enable further learning to promote efficient monitoring and management.

Data collected on the private protected areas adjacent to the $\mathrm{KNP}$, where economic goals are paramount, are analysed as soon as surveys are completed, so that timely management can be implemented (Peel et al. 1999). In the KNP, where biodiversity is the main objective, analysis of previous surveys proved to be very complex. One of the major hurdles in evaluating TPC exceedences in the KNP was an under-estimation of the data processing requirements for the evaluation. The problem is currently being addressed through the development of an automated analysis procedure (Kruger et al. 2008), which should improve the rate and interpretation of monitoring results significantly.

A critical consideration in ensuring the success of the use of TPCs in flagging management concerns is the implementation of the feedback process. Each TPC has to be evaluated according to a defined time schedule and the outcome of the evaluation needs to be reported at a predetermined forum where decisions about the management response to TPC exceedences can be made. In the past, this process has proved successful in private protected areas where an agreement between a client and a service provider exists and where regular feedback (at least annually) forms part of a contractual agreement. The whole TPC process depends on this crucial last step; if the feedback mechanisms fail, the TPC process fails.

\section{Conclusion}

Vast resources may be required to determine unacceptable (with regard to the defined desired state) impact on vegetation due to herbivores or other drivers. A framework was developed to guide resource use by identifying areas of concern, which would allow focused monitoring efforts. In cases where knowledge of the system is particularly limited, reference sites that represent the most important ecological features can be considered in addition to the focused monitoring sites to gain more knowledge of the system's responses. Whatever monitoring approach is used, it is essential to analyse and interpret findings promptly to ensure that the appropriate feedback completes the adaptive management loop in time to enhance the necessary management actions. The combination of a focused and a prompt response makes the monitoring initiative both feasible and useful, and hence likely to be used.

\section{References}

Adler, P.B., Raff, D.A. \& Lauenroth, W.K., 2001, 'The effect of grazing on the spatial heterogeneity of vegetation', Oecologia 128, 456-479.

Archibald, S., 2008, 'African grazing lawns: How fire, rainfall, and grazer numbers interact to affect grass community states', Journal of Wildlife Management 72, 429-501.

Archibald, S., Bond, W.J., Stock, W.D. \& Fairbanks, D.H.K., 2005, 'Shaping the landscape: Fire-grazer interactions in an African savanna', Ecological Applications 15, 96-109.

Asner, G.P., Levick, S., Kennedy-Bowdoin, T., Knapp, A.K., Emerson, R., Jacobson, J., et al., 2009, 'Large-scale impacts of herbivores on the structural diversity of African savannas', Proceedings of the National Academy of Sciences of the United States of America 106(12), 4947-4952.

August, P.V., 1983, 'The role of habitat complexity and heterogeneity in structuring tropical mammal communities', Ecology 64, 1495-1507.

Bezuidenhout, H. \& Brown, L.R., 2008, 'Vegetation description of the Doornhoek section of the Mountain Zebra National Park (MZNP), South Africa', Koedoe 50, 82-92.

Bezuidenhout, H., 1996, 'The major vegetation communities of the Augrabies Falls National Park, Northern Cape. 1. The southern section', Koedoe 39, 7-24.

Bezuidenhout, H., 2004, 'Report on the impact of elephants on the vegetation of the Zwarthoek section, Marakele National Park', unpublished report, Arid Ecosystems Research Unit, Conservation Services, Kimberley.

Biggs, H.C. \& Rogers, K.H., 2003, 'An adaptive system to link science, monitoring and management in practise,' in J.T. du Toit, K.H. Rogers \& H.C. Biggs (eds.), The Kruger Experience: Ecology and management of savanna heterogeneity, pp. 59-80, Island Press, Washington DC.

Biggs, R., Carpenter, S. \& Brock, W.A., 2009, 'Turning back from the brink: Detecting an impending regime shift in time to avert it', Proceedings of the National Academy of Sciences of the United States of America 106, 826-831. 
Blose, A., 2007, 'Influence of large mammals on woody vegetation heterogeneity along the Sabie and Letaba Rivers in Kruger National Park', BSc(hons) dissertation, School of Animal, Plant and Environmental Sciences, University of the Witwatersrand.

Bond, W.J. \& Loffell, D., 2001, 'Introduction of giraffe changes acacia distribution in a South African savanna', African Journal of Ecology 39, 286-294.

Bond, W.J. \& Van Wilgen, B.W., 1996, Fire and Plants, Chapman \& Hall, London.

Bothma, J. du. P., Peel, M.J.S., Pettit, S. \& Grossman, D., 1990, 'Evaluating the accuracy of some commonly used game-counting methods', South African Journal of Wildlife Management 20(1), 26-32.

Botkin, D.B., Melillo, J.M. \& Wu, L.S.Y., 1978, 'How ecosystem processes are linked to large mammal population dynamics,' in C.W. Fowler \& T.D. Smith (eds.), Dynamics of large mammal populations, pp. 373-414, John Wiley \& Sons.

Coe, M.J., Cumming, D.H. \& Phillipson, J., 1976, 'Biomass and production of large African herbivores in relation to rainfall and primary production', Oecologia 22, 341-354.

Coetzee, B.J. \& Gertenbach, W.P.D., 1977, 'Technique for describing woody vegetation composition and structure in inventory type classification, ordination and animal habitat surveys', Koedoe 20(1), 67-75.

Coetzee, B.J., Engelbrecht, A.H., Joubert, S.C.J. \& Retief, P.F., 1979, 'Elephant impact on Sclerocarya caffra trees in Acacia nigrescens tropical plains thornveld of the Kruger National Park', Koedoe 22, 39-60.

Collinson, R.F.H. \& Goodman, P.S., 1982, 'An assessment of range condition and large herbivore carrying capacity of the Pilanesberg Game Reserve, with guidelines and recommendations for management', Inkwe 1, 1-54.

Cromsigt, J.P.G.M. \& Olff, H., 2006, 'Resource partitioning among savanna grazers mediated by local heterogeneity: an experimental approach', Ecology 87(6), 1532-1541.

Cromsigt, J.P.G.M., Prins, H.H.T. \& Olff, H., 2009, 'Habitat heterogeneity as a driver of ungulate diversity and distribution patterns: interaction of body mass and digestive strategy', Diversity and Distributions 15, 513-515.

Cumming, D.H.M., Fenton, M.B., Rautenbach, I.L., Taylor, R.D., Cumming, G.S., Cumming, M.S., et al., 1997, 'Elephants, woodlands and biodiversity in southern Africa', South African Journal of Science 93, 231-236.

Diaz, S., Noy-Meir, I. \& Cabido, M., 2001, 'Can grazing response of herbaceous plants be predicted from simple vegetative traits?', Journal of Applied Ecology 38, 497-508.

Dörgeloh, W.G., Van Hoven, W. \& Rethman, N.F.G., 1998, 'Faecal analysis as an indicator of the nutritional status of the diet of roan antelope in South Africa', South African Journal of Wildlife Research 28, 16-23.

Druce, D.J., Shannon, G., Page, B., Grant, R. \& Slotow, R., 2008, 'Ecological thresholds in the savanna landscape: developing a protocol for monitoring the change in composition and utilisation of large trees', PLOS ONE 3(12): e3979. doi:10.1371

Du Toit, J.T. \& Owen-Smith, N., 1989, 'Body size, population metabolism and habitat specialization among large African herbivores', The American Naturalist 133(5), $736-740$

Duncan, D.H. \& Wintle, B.A., 2008, 'Towards adaptive management of native vegetation in regional landscapes', in Landscape analysis and visualisation. vegetation in regional landscapes', in Landscape analysis and visualisation.
Lecture Notes in Geoinformation and Cartography, Part 2, pp. 159-182, Springer, Lecture
Berlin.

Eckhardt, H.C., Van Wilgen, B.W. \& Biggs, H.C., 2000, 'Trends in woody vegetation cover in the Kruger National Park, South Africa, between 1940 and 1998.', African cover in the Kruger National Park,
Journal of Ecology 38, 108-115.

Fritz, H. \& Duncan, P., 1994, 'On the carrying capacity for large ungulates of African savanna ecosystems', Proceedings of the Royal Society of London B 256, 77-82.

Fuhlendorf, S.D. \& Engle, D.M., 2001, 'Restoring heterogeneity on rangelands: ecosystem management based on evolutionary grazing patterns', BioScience 51, 625-632.

Fynn, R.W.S. \& O'Connor, T.G., 2000, 'Effect of stocking rate and rainfall on rangeland dynamics and cattle performance in a semi-arid savanna, South Africa', Journal of Applied Ecology 37, 491-507.

Gaylard, A., Owen-Smith, N. \& Redfern, J.V., 2003, 'Surface water availability: Implication for heterogeneity and ecosystem processes,' in J.T. du Toit, K.H. Rogers \& H.C. Biggs (eds.), The Kruger Experience: Ecology and management of savanna heterogeneity, pp. 171-188, Island Press, Washington DC.

Gertenbach, W., 1983, 'Landscapes of the Kruger National Park', Koedoe 26, 9-121.

Gordon, I.J., Hester, A.J. \& Festa-Bianchet, M., 2004, 'The management of wild large herbivores to meet economic, conservation and environmental objectives', Journal of Applied Ecology 41, 1021-1031.

Gotze, A.R., Cilliers, S.S., Bezuidenhout, H. \& Kellner, K., 2008, 'Analysis of the vegetation of the sandstone ridges (Ib land type) of the north-eastern parts of the Mapungubwe National Park, Limpopo Province, South Africa', Koedoe 50, 72-81.

Grant, C.C. \& Scholes, 2006, 'The importance of nutrient hot-spots in the conservation and management of large wild mammalian herbivores in semi-arid savannas', Biological Conservation 130, 426-437.

Grant, C.C. \& Scholes, M.C., 2003, 'Determining the scales at which nutrients act as drivers of herbivore distribution in the Kruger National Park', African Journal of Range and Forage Science 20, 74.

Grant, C.C. \& Van der Walt, J.L., 2000, 'Towards an adaptive management approach for the conservation of rare antelope in the Kruger National Park: outcome of a workshop held in May 2000', Koedoe 43, 103-112.
Grant, C.C., Balfour, D., Hofmeyr, M. \& Kruger, L., 2007, 'A framework for understanding elephant effects on woodland', in J.J. Bester, A.H.W. Seydack, T. Vorster, I.J. van der Merwe \& S. Dzivhani (eds.), Multiple use management of natural forests der Merwe \& S. Dzivhani (eds.), Multiple use management of natural forests and woodlands: policy refinement and progress. Natural forests and savanna woodlands

Grant, C.C., Davidson, T., Funston, P.J. \& Pienaar, D.J., 2002, 'Challenges faced in the conservation of rare antelope: a case study on the northern basalt plains of the Kruger National Park', Koedoe 45, 45-66.

Grant, C.C., Peel, M.J.S., Zambatis, N. \& Van Ryssen, J.B.J., 2000, 'Nitrogen and phosphorus concentration in faeces: an indicator of range quality as a practical adjunct to existing evaluation methods', African Journal of Range and Forage Science 17, 81-92.

Grant, C.C., Smit, I.P.J., Novellie, P., Kruger, L., Vickers, K. \& Gaylard, A., in review, 'Heterogeneity: What is sufficient and how can it be measured?', Koedoe.

Guldemond, R. \& Van Aarde, R., 2007, 'The impact of elephants on plants and their community variables in South Africa's Maputaland', African Journal of Ecology, 45, 327-335.

Hanley, T.A., 1982, 'The nutritional basis for food selection by ungulates', Journal of Range Management 35, 146-151.

Harrington, R., Biggs, H.C., Owen-Smith, N. \& Viljoen, P.C., 1999, 'The roan antelope decline in northern Kruger National Park: spatial analysis of herbivore and vegetation changes using GIS.', South African Journal of Wildlife Research 96, 69-78.

Hartmann, I., 2009, 'Can elephant impact influence the diversity of riparian tree species?', diploma thesis, Department of Vegetation Ecology, Technische Universitaet Muenchen Freising.

Ihwagi, F.W., Vollrath, F., Chira, R.M., Douglas-Hamilton, I. \& Kironchi, G., 2010, 'The impact of elephants, Loxodonta africana, on woody vegetation through selective debarking in Samburu and Buffalo Springs National Reserves, Kenya', African Journal of Ecology 48, 87-95.

Kerley, G.I.H. \& Landman, M., 2006, 'The impact of elephant on biodiversity in the Eastern Cape Subtropical thickets', South African Journal of Science 102, 1-8.

Kruger, J.M., Jones, M., Schildauer, M. \& Stevens, N., 2008, 'New technologies for automating the management and analysis of conservation data', Ecological Circuits 1, 5-29.

Landman, M. \& Kerley, G.I.H., 2009, 'Elephant impacts and potential indicators of elephant-induced change to vegetation composition and structure in Addo Elephant National Park: Baseline assessment of key-plant species in Colchester, Kuzuko Contractual Park and the Darlington monitoring exclosures', Report by the Centre for African Conservation Ecology, Nelson Mandela Metropolitan University, Port Elizabeth.

Lombard, A.T., Johnson, C.F., Cowling, R.M. \& Pressey, R.L., 2001, 'Protecting plants from elephants: botanical reserve scenarios within the Addo Elephant National Park, South Africa', Biological Conservation 102, 191-203.

Ludwig, F., 2001, 'Tree-grass interactions on an East African Savanna: The effects of competition, facilitation and hydraulic lift', PhD thesis published in Tropical Resource Management Papers, no 39, Wageningen University and Research Resource Management
Centre, Wageningen.

Ludwig, J.F., Tongway, D., Bastin, G.N. \& James, C.D., 2004, 'Monitoring ecological indicators of rangeland functional integrity and their relation to biodiversity at local to regional scales', Austral Ecology 29, 108-120.

McGeoch, M.A., Sithole, H., Samways, M.J., Simaika, J.P., Pryke, J.S., Picker, M., et al., 2011, 'Monitoring terrestrial and freshwater invertebrates in protected areas', Koedoe 53(2), Art. \#1000, 13 pages. doi:10.4102/koedoe.v53i2.1000.

McGinty, W.A., Smeins, F.E. \& Merril, L.B., 1979, 'Influence of soil, vegetation, and grazing management on infiltration rate and sediment production of Edwards grazing management on infiltration rate and sediment production
Plateau Rangeland', Journal of Range Management 32, 33-37.

McNaughton, S.J., 1979, 'Grazing as an optimization process: grass-ungulate relationships in the Serengeti', The American Naturalist 113, 601-703.

McNaughton, S.J., Oesterheld, M., Frank, D.A. \& Williams, K.J., 1989, 'Ecosystem-level pattern of primary productivity and herbivory in terestrial habitats', Nature 341, 142-144. doi:10.1038/341142a0, PMid:2779651

Mentis, M.T. \& Duke, R.R., 1976, 'Carrying capacities of natural veld in Natal for large wild herbivores', South African Journal of Wildlife Research 6, 65-74.

Mills, M.G.L., Biggs, H.C. \& Whyte, I.J., 1995, 'The relationship between rainfall, lion predation and population trends in African herbivores', Wildlife Research 22, 75-88. doi:10.1071/WR9950075

Muller, F., 2005, 'Ecosystem indicators for the integrated management of landscape health and integrity', in S.E. Jorgensen, R. Costanza \& F.L. Xu (eds.), Handbook of Ecological indicators for assessment of ecosystem health, pp. 277-303, Taylor \& Francis, London. doi:10.1201/9780203490181.ch12

Murwira, A., 2003, 'Scale matters! A new approach to quantify spatial heterogeneity for predicting the distribution of wildlife', PhD thesis, Wageningen University.

Mutanga, O., Prins, H.H.T., Skidmore, A.K., Van Wieren, S., Huizing, H., Grant, C.C.R., et al., 2004, 'Explaining grass-nutrient patterns in a savanna rangeland 2699.2004.01072.x

Mysterud, A., 2006, 'The concept of overgrazing and its role in management of large herbivores', Wildlife Biology 12, 129-141. doi:10.2981/0909-6396(2006)12[129:TC OOAI]2.0.CO;2

Naiman, R.J., Braack, L.E.O., Grant, C.C., Kemp, A.C., Du Toit, J.T. \& Venter, F.J., 2003, 'Interactions between species and ecosystem characteristics,' in J.T. du Toit, K.H. Rogers \& H.C. Biggs (eds.), The Kruger Experience: Ecology and management of savanna heterogeneity, pp. 221-241, Island Press, Washington DC. 
Noss, R.F., 1990, 'Indicators for monitoring biodiversity: a hierarchical approach', Conservation Biology 44, 355-364.

Ogutu, J. \& Owen-Smith, N., 2003, 'ENSO, rainfall and temperature influences on extreme population declines among African savanna ungulates', Ecology Letters 6, 412-419. doi:10.1046/j.1461-0248.2003.00447.x

O'Reagain, P.J. \& Turner, J.R., 1992, 'An evaluation of the empirical basis for grazing management recommendations for rangeland in southern Africa', Journal of the Grassland Society of Southern Africa 9(1), 38-49.

Owen-Smith, N., 1985, 'The ecology of browsing by African wild ungulates,' in J.C. Tothill \& J.J. Mott (eds.), International Savanna Symposium: Ecology and Management of the World's Savannas, Brisbane, Australia, May 28-31, 1984, pp. 345-349.

Owen-Smith, N., 1996, 'Ecological guidelines for waterpoints in extensive protected areas', South African Journal of Wildlife Research 26, 107-112.

Peel, M., Stalmans, M. \& Anderson, J., 2009, 'Management Plan: Associated Private Nature Reserves', unpublished land owner document.

Peel, M.J.S., 2005, 'Towards a predictive understanding of savanna vegetation eastern Lowveld of South Africa: with implications for effective management', PhD thesis, University of KwaZulu-Natal.

Peel, M.J.S. \& Bothma, J. du P., 1995, 'Comparison of the accuracy of four methods commonly used to count impala', South African Journal of Wildlife Research 25(22), 41-43.

Peel, M.J.S., Biggs, H.C. \& Zacharias, P.J.K., 1999, 'The evolving use of indices currently based on animal number and type in semi-arid heterogeneous landscapes and complex systems', African Journal of Range and Forage Science 15, 117-127. doi: 10.1080/10220119.1998.9647953

Peel, M.J.S., Kruger, J.M. \& MacFadyen, S., 2007, 'Woody vegetation changes of a mosaic of protected areas adjacent to the Kruger National Park, South Africa', Journal of Vegetation Science 18, 807-814. doi:10.1658/1100-9233(2007)18[807:WVOAMO ]2.0.CO;2, doi:10.1111/j.1654-1103.2007.tb02597.x

Peel, M.J.S., Kruger, J.M. \& Zacharias, P.J.K., 2005, 'Environmental and management determinants of vegetation state on the Eastern Lowveld of South Africa', African Journal of Ecology 43, 352-361. doi:10.1111/j.1365-2028.2005.00590.x

Pickett, S.T.A., Cadenasso, M.L. \& Benning, T.L., 2003, 'Biotic and abiotic variability as key determinants of savanna heterogeneity at multiple spatiotemporal scales,' in J.T. du Toit, K.H. Rogers \& H.C. Biggs (eds.), The Kruger Experience: Ecology and management of savanna heterogeneity, pp. 22-40, Island Press, Washington DC.

Rebelo, T.G., Freitag-Ronaldson, S., Cheney, C. \& McGeoch, M., 2011, 'Prioritising species of special concern in the Table Mountain National Park for monitoring: The challenge of a species-rich, threatened ecosystem', Koedoe 53(2), Art. \#1019, 14 pages. doi: 10.4102/koedoe.v53i2.1019

Redfern, J.V., Viljoen, P.C., Kruger, J.M. \& Getz, W.M., 2002, 'Biases in estimating population size from an aerial census: a case study in the Kruger National Park, population size from an aerial census: a case study in the
South Africa', South African Journal of Science $98,455-461$.

Rogers, K.H., 2003, 'Adopting a heterogeneity paradigm: Implications for management of protecteed areas,' in J.T. du Toit, K.H. Rogers \& H.C. Biggs (eds.), The Kruger
Experience: Ecology and management of savanna heterogeneity, pp. 41-58, Island Press, Washington DC.

Rogers, K.H. \& O'Keeffe, J., 2003, 'River heterogeneity: ecosystem structure, function and management', in J.T. du Toit, K.H. Rogers \& H.C. Biggs (eds.), The Kruger Island Press, Washington DC.

Roux, D. \& Foxcroft, L.C., 2011, 'The development and application of strategic adaptive management within South African National Parks' areas', Koedoe 53(2), Art. \#1049, 5 pages. doi:10.4102/koedoe.v53i2.1049.

Rubin, F., 1998, 'The physical environment and major plant communities of the Tankwa- Karoo National Park', Koedoe 41, 61-94.

Rubin, F. \& Palmer, A.R., 1996, 'The physical environment and major plant communities of the Karoo National Park, South Africa', Koedoe 39, 25-52.

Sankaran, M., Ratnam, J. \& Hanan, N., 2004, 'Tree-grass coexistence in savannas revisited: insights from an examination of assumptions and mechanisms invoked in existing models', Ecology Letters 7, 480-490. doi:10.1111/j.14610248.2004.00596.x

SANParks. See South African National Parks.

Scarnecchia, D.L., 1988, 'Grazing, stocking, and production efficiencies in grazing research', Journal of Range Management 41, 279-281. doi:10.2307/3899378

Schmitz, O.J., 2008, 'Herbivory from individuals to ecosystems', Annual Review of Ecology, Evolution and Systematics 39, 133-152. doi:10.1146/annurev. ecolsys.39.110707.173418

Scholes, R.J., 2003, 'Convex relationships in ecosystems containing mixtures of trees and grass', Environmental and Resource Economics 26, 559-574. doi:10.1023/ B:EARE.0000007349.67564.b3

Scholes, R.J., 2009, 'Syndromes of dryland degradation in southern Africa', African Journal of Range and Forage Science 26(3), 113-125. doi:10.2989/
AJRF.2009.26.3.2.947

Scholes, R.J. \& Archer, S.R., 1997, 'Tree-grass interactions in savannas', Annual Review of Ecology and Systematics 28, 517-544. doi:10.1146/annurev.ecolsys.28.1.517

Scholes, R.J. \& Kruger, J.M., 2011, 'A framework for deriving and triggering thresholds for management intervention in uncertain, varying and time-lagged systems', Koedoe 53(2), Art. \#987, 8 pages. doi:10.4102/koedoe.v53i2.987
Senft, R.L., Coughenour, M.B., Baily, D.W., Rittenhouse, L.R., Sala, O.E. \& Swift, D.M., 1987, 'Large herbivore foraging and ecological hierarchies', BioScience 37, D.M., 1987, 'Large herbivore fo
789-799. doi:10.2307/1310545

Shackleton, C., 1998, 'The prediction of woody plant productivity in the savanna biome, South Africa', PhD thesis, University of Witwatersrand.

Shannon, G., Druce, D.J., Page, B., Eckhardt, H.C., Grant, R. \& Slotow, R., 2008, 'The utilization of large savanna trees by elephant in southern Kruger National 'Park', Journal of Tropical Ecology 24, 281-289. doi:10.1017/S0266467408004951

Siebert, F. \& Eckhardt, H.C., 2008, 'The vegetation and floristics of the Nkhuhlu Exclosures, Kruger National Park', Koedoe 50, 126-144.

Skarpe, C., Aarrestad, P.A., Andreassen, H.P., Dhillion, S.S., Dimakatso, T., Du Toit, J.T., et al., 2004, 'The return of the giants: ecological effects of an increasing elephant population', Ambio 33, 276-282. doi:10.1639/0044-7447(2004)033[0276:TROTGE population', Ambio 33, 276-282. doi:10.1639/0044-7447/2004)
]2.0.CO;2, doi:10.1579/0044-7447-33.6.276, PMid:15387059

Smit, I.P.J. \& Ferreira, S.M., 2010, 'Management intervention affects river-bound spatial dynamics of elephants', Biological Conservation 143, 2172-2181.

Smit, I.P.J., Grant, C.C. \& Devereux, B.J., 2007, 'Do artificial waterholes influence the way herbivores use the landscape? Herbivore distribution patterns around rivers and artificial surface water sources in a large African Savanna park', Biological Conservation 136, 85-99. doi:10.1016/j.biocon.2006.11.009

Snyman, H.A., 2005, 'Rangeland degradation in a semi-arid South Africa - 1: influence of seasonal root distribution, root/shoot ratios and water-use efficiency', Journal of Arid Environments 60, 457-481. doi:10.1016/j.jaridenv.2004.06.006

Snyman, H.A., 2009, 'Root studies on grass species in a semi-arid South Africa along a degradation gradient', Agriculture, Ecosystems and Environment 130, 100-108. a degradation gradient', Agricult
doi:10.1016/j.agee.2008.12.003

South African National Parks, 2006, Coordinated policy framework governing park management plans (Draft 3), South African National Parks, Pretoria.

South African National Parks, 2008, Park Management Plan: Kruger National Park (Draft), South African National Parks, Pretoria.

South African National Parks, 2010, Elephant Management Plan: Kruger National Park (Draft), South African National Parks, Pretoria.

Staver, C., Bond, W.J., Stock, W.D., Van Rensburg, S.J. \& Waldram, M., 2009, 'Browsing and fire interact to suppress tree density in an African savanna', Ecological and fire interact to suppress tree density in an African savanna',
Applications 19, 1909-1919. doi:10.1890/08-1907.1, PMid:19831079

Stock, W.D., Bond, W.J. \& Van de Vijver, C.A.D.M., 2009, 'Herbivore and nutrient control of lawn and bunch grass distributions in a southern African savanna', Plant Ecology 206(1), 15-27. doi:10.1007/s11258-009-9621-4

Traill, L.W., 2004, 'Seasonal utilization of habitat by large herbivores in semi-arid Zimbabwe', South African Journal of Wildlife Research 34, 13-24.

Treydte, A.C., Heitkonig, I.M.A., Prins, H.H.T. \& Ludwig, F., 2007, 'Trees improve grass quality for herbivores in African savannas', Perspectives in Plant Ecology, Evolution and Systematics 8, 197-205. doi:10.1016/j.ppees.2007.03.001

Treydte, A.C., Van Beeck, L., Ludwig, F. \& Heitkonig, I.M.A., 2008, 'Improved quality of beneath-canopy grass in South African savannas: Local and seasonal variation', Journal of Vegetation Science 19, 663-670. doi:10.3170/2008-8-18435

Trollope, W.S.W., 1990a, 'Development of a technique for assessing veld condition in the Kruger National Park', Journal of the Grassland Society Southern Africa 7 , 46-51.

Trollope, W.S.W., 1990b, 'Veld management with specific reference to game ranching in the grassland and savanna areas of South Africa', Koedoe 33, 77-86.

Turner, M.G., Pearson, S.M., Romme, W.H. \& Wallace, L.L., 1997, 'Landscape heterogeneity and ungulate dynamics: What spatial scales are important?', in J.A. Bisonette (ed.), Wildlife and landscape ecology: effects of pattern and scale, pp. 331-348, Springer Verlag, New York.

Van de Koppel, J., Rietkerk, M., Van Langevelde, F., Kumar, L., Klausmeier, C.A., Fryxell, J.M., et al., 2002, 'Spatial heterogeneity and irreversible vegetation change in semiarid grazing systems', The American Naturalist 159, 209-218. doi:10.1086/324791, PMid:18707414

Van Rooyen, M.W., Van Rooyen, N., Bothma, J. du P. \& Van den Berg, H.M., 2008, 'Landscapes in the Kalahari Gemsbok National Park, South Africa', Koedoe 50, 99-112.

Van Staden, P.J. \& Bredenkamp, G.J.L., 2006, 'A floristic analysis of forest and thicket vegetation of the Marakele National Park', Koedoe 49, 15-31.

Van Wilgen, B.W., Govender, N., Forsyth, G.G. \& Kraaij, T., 2011, 'Towards adaptive fire management for biodiversity conservation: Experience in South African National Parks', Koedoe 53(2), Art. \#982, 9 pages. doi:10.4102/koedoe.v53i2.982

Van Wilgen, B.W., Govender, N. \& Biggs, H.C., 2007, 'The contribution of fire research to fire management: a critical review of a long-term experiment in the Kruger
National Park, South Africa', International Journal of Wildland Fire 16, 519-530. National Park, South
doi:10.1071/WF06115

Van Wilgen, B.W., Govender, N. \& MacFadyen, S., 2008, 'An assessment of the implementation and outcomes of recent changes to fire management in the Kruger National Park', Koedoe 50(1), 22-31.

Venter, F.J., 1986, 'Soil patterns associated with the major geological units of the Kruger National Park', Koedoe 29, 125-138.

Venter, F.J., Scholes, R.J. \& Eckhardt, H.C., 2003, 'The abiotic template and its associated vegetation pattern,' in J.T. du Toit, K.H. Rogers \& H.C. Biggs (eds.), The Kruger Experience: Ecology and man
83-129, Island Press, Washington DC.

Viljoen, A.J., 1995, 'The influence of the 1991/1992 drought on the woody vegetation of the Kruger National Park', Koedoe 38, 85-97. 
Vlek, P.L.G., Le, Q.B. \& Tamene, L., 2008, Land decline in land-rich Africa: A creeping disaster in the making, CGIAR Science Council Secretariat, Rome.

Walker, B.H. \& Goodman, P.S., 1983, 'Some implications of ecosystem properties for wildlife management,' in N. Owen-Smith (ed.), Management of large mammals in african conservation areas, pp. 79-80, HAUM, Pretoria.

Walker, B.H., Emslie, R.H., Owen-Smith, N. \& Scholes, R.J., 1987, 'To cull or not to cull: lessons from a southern African drought', Journal of Applied Ecology 24, 381-401. doi:10.2307/2403882

Ward, D., 2005, 'Do we understand the causes of bush encroachment in African savannas?', African Journal of Range and Forage Science 22, 101-105. doi:10.2989/10220110509485867

Wentzel, J.J., Bothma, J. du P. \& Van Rooyen, N., 1991, 'Characteristics of the herbaceous layer in preferred grazing areas of six herbivore species in the southeastern Kruger National Park', Koedoe 34(1), 51-59.

Woolnough, A.P. \& Du Toit, J.T., 2001, 'Vertical zonation of browse quality in tree canopies exposed to a size-structured guild of African browsing ungulates', Oecologia 129, 585-590.
Wrench, J.M., Meissner, H.H. \& Grant, C.C., 1997, 'Assessing diet quality of African ungulates from faecal analysis: the effect of forage quality, intake and herbivore species', Koedoe 40(1), 125-136.

Yeaton, R.I., 1988, 'Porcupines, fire and the dynamics of the tree layer of the Burkea africana savanna', Journal of Ecology 76, 1017-1029. doi:10.2307/2260630

Young, K.D., Ferreira, S.M. \& Van Aarde, R., 2009a, 'Elephant spatial use in wet and dry savannas of southern Africa', Journal of Zoology 278, in 17 doi:10.1111/j.1469-7998.1984.tb06041.x, doi:10.1111/j.14697998.2009.00568.x

Young, K.D., Ferreira, S.M. \& Van Aarde, R., 2009b, 'The influence of increasing population size and vegetation productivity on elephant distribution in the Kruger National Park', Austral Ecology 34, 329-342. doi:10.1111/j.1442Kruger National Park

Zambatis, N., 2002, 'Revised procedures for veld condition assessment in the Kruger National Park', Internal Report 1/2002, Scientific Services, South African National Parks, Skukuza. 